\title{
Utilization to Remove Pb (II) Ions from Aqueous Environments Using Waste Fish Bones by Ion Exchange
}

\author{
Bayram Kizilkaya $^{1}$ and A. Adem Tekınay ${ }^{2}$ \\ ${ }^{1}$ Faculty of Marine Sciences and Technology, Canakkale Onsekiz Mart University, 17100 Canakkale, Turkey \\ ${ }^{2}$ Faculty of Fisheries, Izmir Katip Celebi University, 35620 Cigli/Izmir, Turkey \\ Correspondence should be addressed to Bayram Kizilkaya; bayram342001@yahoo.com
}

Received 2 May 2013; Revised 3 March 2014; Accepted 17 March 2014; Published 29 April 2014

Academic Editor: Huu Hao Ngo

Copyright ( 2014 B. Kizilkaya and A. A. Tekınay. This is an open access article distributed under the Creative Commons Attribution License, which permits unrestricted use, distribution, and reproduction in any medium, provided the original work is properly cited.

\begin{abstract}
Removal of lead (II) from aqueous solutions was studied by using pretreated fish bones as natural, cost-effective, waste sorbents. The effect of $\mathrm{pH}$, contact time, temperature, and metal concentration on the adsorption capacities of the adsorbent was investigated. The maximum adsorption capacity for $\mathrm{Pb}$ (II) was found to be $323 \mathrm{mg} / \mathrm{g}$ at optimum conditions. The experiments showed that when $\mathrm{pH}$ increased, an increase in the adsorbed amount of metal of the fish bones was observed. The kinetic results of adsorption obeyed a pseudo second-order model. Freundlich and Langmuir isotherm models were applied to experimental equilibrium data of $\mathrm{Pb}$ (II) adsorption and the value of $R_{L}$ for $\mathrm{Pb}$ (II) was found to be 0.906 . The thermodynamic parameters related to the adsorption process such as $E_{a}, \Delta G^{\circ}, \Delta H^{\circ}$, and $\Delta S^{\circ}$ were calculated and $E_{a}, \Delta H^{\circ}$, and $\Delta S^{\circ}$ were found to be $7.06,46.01 \mathrm{~kJ} \mathrm{~mol}^{-1}$, and $0.141 \mathrm{~kJ} \mathrm{~mol}^{-1} \mathrm{~K}^{-1}$ for $\mathrm{Pb}$ (III), respectively. $\Delta H^{\circ}$ values $\left(46.01 \mathrm{kJmol}^{-1}\right)$ showed that the adsorption mechanism was endothermic. Weber-Morris and Urano-Tachikawa diffusion models were also applied to the experimental equilibrium data. The fish bones were effectively used as sorbent for the removal of $\mathrm{Pb}$ (II) ions from aqueous solutions.
\end{abstract}

\section{Introduction}

The contamination with toxic metals is the most important problem facing all over the world. Lead is one of the most toxic metals for living species and people [1]. Many important industrial applications, such as storage battery, manufacturing, printing pigments, fuels, photographic materials, explosive manufacturing, metal plating, mining, painting, car manufacturing, smelters, and metal refineries [2,3], are major sources of $\mathrm{Pb}$ (II) contamination [4]. Lead concentrations come near to $200-500 \mathrm{mg} / \mathrm{L}$ in many industrial wastewaters and it should be reduced to a range of $0.1-0.05 \mathrm{mg} / \mathrm{L}[5,6]$. Different removal methods such as chemical precipitation, ion exchange, membrane filtration, solvent extraction, phytoextraction, ultrafiltration, reverse osmosis, and adsorption have been used to remove heavy metals from water and wastewaters [7-10]. Many of these processes have some disadvantages such as deficient removal, high energy requirement, and new toxic sludge/waste products that need further treatment before disposal [6]. The adsorption procedure is a simple and low-cost method for metal removal [6]. Generally, cost-effective alternative sorbents for heavy metal removal from water resources can be obtained from materials which exist abundantly in nature or arise as byproducts and waste materials from various industries $[8,11]$. Recently, researchers have reported that materials with biological and natural origins, such as agricultural, banana peel, peel waste, and animal waste, are effective and usable in the removal of metals $[9,12-16]$. Some sorbents such as seaweed (Gymnogongrus Torulosus) [17], leaf powder (Ficus religiosa) [18], and bacteria (Tannery Effluents Contaminated Soil) [19] were used for metal removal. Bones are composed of $30 \%$ organic compounds and $70 \%$ inorganics by weight [20]. The inorganic phase consists mainly of hydroxyapatite $\mathrm{Ca}_{10}\left(\mathrm{PO}_{4}\right)_{6}(\mathrm{OH})_{2}$ (HAP) [11, 13]. HAP is an effective inorganic adsorption material because it has a high removal capacity for heavy metals by an ion exchange reaction with calcium ions on the bone surface. Animal bones, a source of biogenic apatite for 
heavy metal removal, have been used as a sorbent source due to their low cost, natural abundance, and efficiency $[11,12,21$, 22].

In this study, the removal of $\mathrm{Pb}$ (II) ions from aqueous environments was investigated using pretreated fish bones. The bogue (Boops boops, Linnaeus 1758) bones were selected as a model fish bone for adsorption. The removal efficiency of the adsorbent was investigated as a function of $\mathrm{pH}$, contact time, initial metal concentration, and temperature. Langmuir and Freundlich models were used to find the adsorption isotherms with the best fit to the experimental data. WeberMorris and Urano-Tachikawa diffusion models were also applied to experimental equilibrium data. Thermodynamic parameters such as $E_{a}, \Delta G^{\circ}, \Delta H^{\circ}$, and $\Delta S^{\circ}$ were calculated to determine the feasibility of the adsorption mechanism. Desorption studies were also carried out to demonstrate reusability of the bone sorbent.

\section{Materials and Methods}

2.1. Preparation and Pretreatment of Bone Sorbents. The fish (Boops boops) were obtained from local fish-shops in Canakkale (TURKEY). Firstly, fish bones were separated from meat and washed with hot distilled water several times. The cleaning procedures are applied at solid to liquid ratio 1:50 for two hours and cleaned with $0.1 \mathrm{M} \mathrm{NaOH}$ solution at $60^{\circ} \mathrm{C}$ and stirring rate $150 \mathrm{rpm}$, denoted as $\mathrm{B}$ [20]. The fish bones were dried in an oven at $50^{\circ} \mathrm{C}$ and then milled to particle sizes between 50 and $200 \mu \mathrm{m}$ with a mortar.

2.2. Apparatus and Chemicals. FT-IR (Perkin Elmer FTIR-Spectrum One, using ATR technique, $4000-550 \mathrm{~cm}^{-1}$ ), SEM-EDX (Phillips XL-30S FEG, analyzed IYTE-Material Research Central/IZMIR), Carbon-Sulfur analyzer (LECO SC-144DR), ICP-AES (Varian Liberty II Series, Sequential Series-Axial, Australia), and Micromeritics-Gemini V for BET surface area were used for the characterization of bone sorbents. ICP-AES was used for the determination of the elements ( $\mathrm{Ca}, \mathrm{Cr}, \mathrm{K}, \mathrm{Mg}, \mathrm{Na}$, and $\mathrm{P}$ ) and controlled with Intel Pentium IV PC and Liberty ICP-Expert Sequential (version: v.30) software. Each measurement was repeated three times $(n=3)$ and then standard errors of the means were calculated. The $\mathrm{pH}$ values of the metal solutions were measured with Consort-C864 (Belgium) multi-pHmeter. Ion chromatography (Shimadzu, Japan) was used to define $\mathrm{NO}_{3}{ }^{-}$within the metal solutions. The equipment was calibrated using Shimadzu anion (P/N 228-33603-93) standard solution prepared at different concentrations.

$\mathrm{Pb}\left(\mathrm{NO}_{3}\right)_{2}$ (Acros, $\geq 98.0 \%$ ) were used for preparing the metal solutions. The $\mathrm{pH}$ of the metal solutions was adjusted with $0.1 \mathrm{M} \mathrm{HNO}_{3}$ and $0.01 \mathrm{M} \mathrm{NaOH}$. $\mathrm{HNO}_{3}$ (Merck, 65\%), $\mathrm{NaOH}$ (Merck, $\geq 97.0 \%$ ), and $\mathrm{NaCl}$ (Merck, $\geq 99.5 \%$ ) were used for the experiments.

2.3. Adsorption Experiments. Adsorption studies were performed in $100 \mathrm{~mL}$ Erlenmeyer flasks containing $0.4 \mathrm{~g}$ bone sorbent and $100 \mathrm{~mL}$ aqueous $\mathrm{Pb}$ (II) solutions, solid to liquid ratio $1: 250$, at a fixed temperature and a stirring rate of
$200 \mathrm{rpm}$ for 30 hours. The temperature was controlled by a water bath consisting of a glass beaker in a magnetic stirrer heater. Dried fish bones (B) were exposed to aqueous metal ions in order to determine their adsorption capacity values. The amount of $\mathrm{Pb}$ (II) (final metal concentration) was determined in the remaining metal solutions after filtration through a $0.45 \mu \mathrm{m}$ Whatman filter by ICP-AES. All adsorption experiments were repeated three times $(n=3)$ and the standard errors of the means were calculated. B was used in the adsorption experiments of $\mathrm{Pb}$ (II). The effect of the initial concentration of the metal ions, $\mathrm{pH}$, contact time, and temperature on the adsorption of $\mathrm{Pb}$ (II) onto $\mathrm{B}$ was investigated.

The adsorption capacities of fish bone as milligram per gram of bone ( $\mathrm{mg} / \mathrm{g}$ fish bone) were calculated with as follows [23]:

$$
q_{e \cdot \exp }=\left(C_{0}-C_{t}\right) \cdot \frac{V}{W},
$$

where $C_{0}$ is the initial concentration of metal ions $(\mathrm{mg} / \mathrm{L})$ and $C_{t}$ is the metal ion concentration after adsorption time $t(\mathrm{mg} / \mathrm{L}) . V$ is the volume of metal ion solutions $(\mathrm{mL})$ and $W$ is the weight of bone $(\mathrm{g}) \cdot q_{e \text { exp }}$ and $q_{e, \text { cal }}$ are the experimental and calculated adsorption capacities ( $\mathrm{mg} / \mathrm{g})$.

\section{Results and Discussion}

3.1. Characterization of Sorbents. The elemental composition of $\mathrm{B}$ and $\mathrm{B}-\mathrm{Pb}$ was determined by Carbon-Sulfur analyzer, ICP-AES, XRD, and SEM-EDX. The carbon, calcium, phosphorus, sodium, magnesium, and sulphur amounts (wt \%) of $\mathrm{B}$ were found to be $10.65 \%, 28.72 \%, 13.58 \%, 0.93 \%$, $0.51 \%$, and $0.04 \%$ by ICP-AES and Carbon-Sulfur analyzer, respectively. $\mathrm{Ca} / \mathrm{P}$ mole ratio of $\mathrm{B}$ was calculated as 1.63 according to the results of previous study [20]. Figure 1 shows the XRD analysis spectrum of B. XRD patterns of bone sorbent prepared in the present study agreed with the reference patterns of calcium phosphate $\left(\mathrm{Ca}_{2} \mathrm{P}_{2} \mathrm{O}_{7}\right.$, Ref. Code, 00-003-0605). Table 1 gives some physical results of surface analysis of $B$ as surface area $\left(\mathrm{m}^{2} / \mathrm{g}\right)$, pore volume $\left(\mathrm{cm}^{3} / \mathrm{g}\right)$, and average pore width $(\AA)$. The analysis of surface area is useful in determining the surface details of the sorbent. The specific surface area of B was determined with the BET method by using nitrogen. Single point surface area of B was found to be $27.72 \mathrm{~m}^{2} / \mathrm{g}$. BJH pore volume, BET, and $\mathrm{BJH}$ pore widthwere determined as $2,83 \times 10^{-2} \mathrm{~cm}^{3} / \mathrm{g}, 26.58$, and 43.58 $\AA$, respectively.

The FT-IR analysis of $\mathrm{B}$ and $\mathrm{B}-\mathrm{Pb}$ is given in Figure 2. The bands at $3300 \mathrm{~cm}^{-1}$ are assigned to $-\mathrm{OH}$ stretching. The peaks at $1020 \mathrm{~cm}^{-1}, 963 \mathrm{~cm}^{-1}, 600 \mathrm{~cm}^{-1}$, and $558 \mathrm{~cm}^{-1}$ are assigned to vibrations of $-\mathrm{PO}_{4}{ }^{-3}$ groups. The stretching and bending modes of $-\mathrm{CO}_{3}{ }^{-2}$ groups were attributed to peaks at $1413 \mathrm{~cm}^{-1}$ and $872 \mathrm{~cm}^{-1}$. The $-\mathrm{CO}_{3}{ }^{-2}$ and $-\mathrm{PO}_{4}{ }^{-3}$ band intensities of $\mathrm{B}$ at $1413 \mathrm{~cm}^{-1}$ and $1020 \mathrm{~cm}^{-1}$ reduced when the $\mathrm{Pb}$ (II) was adsorbed onto its surface (Figure 2). It could be said that the adsorption of $\mathrm{Pb}$ ions from aqueous solutions the surfaces of bone sorbents were changed to vibrations of $-\mathrm{CO}_{3}{ }^{-2}$ and $-\mathrm{PO}_{4}{ }^{-3}$ groups. 


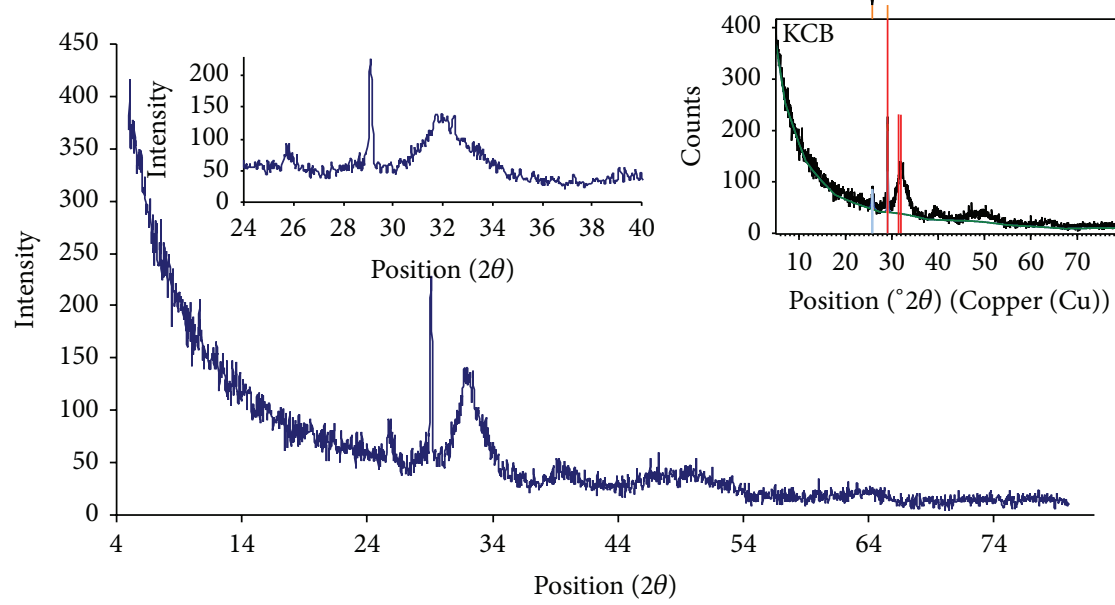

FIGURE 1: XRD spectra of B.

TABLE 1: Some physical results of BET surface analysis of pretreated fish bone.

\begin{tabular}{|c|c|c|c|c|c|}
\hline \multirow{2}{*}{ Surface Area $\left(\mathrm{m}^{2} / \mathrm{g}\right)$} & BET & Langmiur & SPSA $^{1}$ & $t$-Plot & $\mathrm{BJH}^{2}$ \\
\hline & 13.45 & 101.60 & 27.72 & 28.06 & 25.97 \\
\hline \multirow{2}{*}{ Pore Volume $\left(\mathrm{cm}^{3} / \mathrm{g}\right)$} & \multicolumn{2}{|c|}{ SPAV $^{3}$} & \multicolumn{2}{|c|}{$t$-plot microvolume } & $\mathrm{BJH}^{4}$ \\
\hline & & & \multicolumn{2}{|c|}{$7.0 \times 10^{-5}$} & $2.83 \times 10^{-2}$ \\
\hline \multirow{2}{*}{ Average Pore Width $(\AA ̊)$} & & & \multicolumn{3}{|c|}{$\mathrm{BJH}(4 \mathrm{~V} / \mathrm{A})$} \\
\hline & \multicolumn{2}{|c|}{26.58} & \multicolumn{3}{|c|}{43.58} \\
\hline
\end{tabular}

SPSA $^{1}$ : single point surface area at $\mathrm{p} / \mathrm{p}^{\circ}$.

$\mathrm{BJH}^{2}$ : $\mathrm{BJH}$ adsorption cumulative surface area of pores between $17.000 \AA$ and $3000.000 \AA$ width.

$\mathrm{SPAV}^{3}$ : single point adsorption total pore volume of pores less than $14.767 \AA$ width at $\mathrm{p} / \mathrm{p}^{\circ}$.

$\mathrm{BJH}^{4}$ : BJH adsorption cumulative volume of pores between $17.000 \AA$ and $3000.000 \AA$ width.

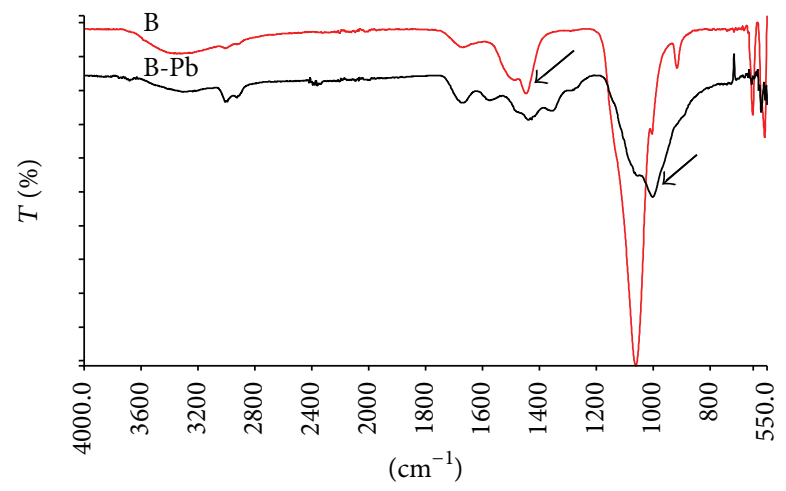

FIgURE 2: FT-IR spectra of B and B-Pb.

The adsorption of $\mathrm{Pb}^{2+}$ ions on to the fish bone surfaces can be explained with two different mechanisms. In the first adsorption mechanism, an ion exchange reaction occurred between metal ions in solution and $\mathrm{Ca}^{2+}$ ions of HAP on the bone surface $[20,24,25]$. This main removal mechanism is as the following reaction $(a)$ :

$$
\begin{gathered}
\mathrm{HAP}-\mathrm{Ca}_{10} \cdot\left(\mathrm{PO}_{4}\right)_{6} \cdot(\mathrm{OH})_{2(\text { Surface })}+x \mathrm{~Pb}^{2+}+2 x \mathrm{NO}_{3}{ }^{-} \\
\longrightarrow \mathrm{Ca}_{(10-x)} \cdot \mathrm{Pb}_{x} \cdot\left(\mathrm{PO}_{4}\right)_{6}(\mathrm{OH})_{2}+x \mathrm{Ca}^{2+}+2 x \mathrm{NO}_{3}{ }^{-}
\end{gathered}
$$

On the other hand, the second adsorption mechanism (b) took place between metal ions and $\mathrm{Na}^{+}$ions of HAP which was formed to HAP-(ONa) due to the alkali cleaning procedure (with $\mathrm{NaOH}$ solution) of the bone surface (c) [20]. These reactions $(b)$ and $(c)$ are given below:

$$
\begin{aligned}
& (\mathrm{HAP}-\mathrm{ONa})_{2}^{+}+x \mathrm{~Pb}^{2+}+2 x \mathrm{NO}_{3 \mathrm{aq}}^{-} \\
& \longrightarrow(\mathrm{HAP}-\mathrm{O})-\mathrm{Pb}-(\mathrm{O}-\mathrm{HAP})+x \mathrm{Ca}^{2+}+2 x \mathrm{NO}_{3}{ }^{-} \\
& \mathrm{Ca}_{10}\left(\mathrm{PO}_{4}\right)_{6}(\mathrm{OH})_{2 \text { (Surface })}+2 \mathrm{Na}^{+}+2 \mathrm{OH}^{-} \\
& \longrightarrow \mathrm{Ca}_{10}\left(\mathrm{PO}_{4}\right)_{6}(\mathrm{ONa})_{2}+2 \mathrm{H}_{2} \mathrm{O}
\end{aligned}
$$

The initial concentration of $\mathrm{NO}_{3}{ }^{-}$ions in the solutions was not changed by the ion exchange reaction between metal ions and $\mathrm{Ca}^{2+}$ ions on the bone surface.

Table 2 and Figure 3 show the SEM-EDX analysis of $B$ and $\mathrm{B}-\mathrm{Pb}$. The calcium percentages for $\mathrm{B}$ and $\mathrm{B}-\mathrm{Pb}$ were found to be $36.44 \%$ and $14.63 \%$ and the $\mathrm{Ca} / \mathrm{P}$ mole ratios of $\mathrm{B}$ and $\mathrm{B}-$ $\mathrm{Pb}$ were calculated as 1.60 and 1.06 , respectively. The results in Figure 3 and Table 1 verified the Pb (II) adsorption on the bone surface by ion-exchange with calcium. Scanning electron microscope (SEM) images are useful in determining the surface and adsorption details of the bone sorbent during the adsorption [20]. The SEM images (Figure 4) show that the surfaces of B are slick and smooth. The surfaces of B$\mathrm{Pb}$ exhibited roughness compared to the surfaces of $\mathrm{B}_{\mathrm{BBB}}$. 


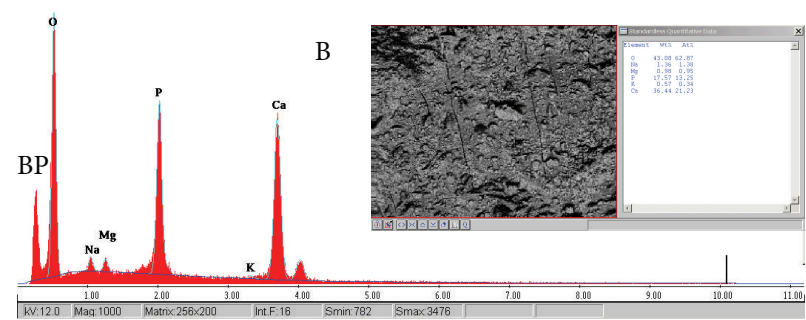

(a)

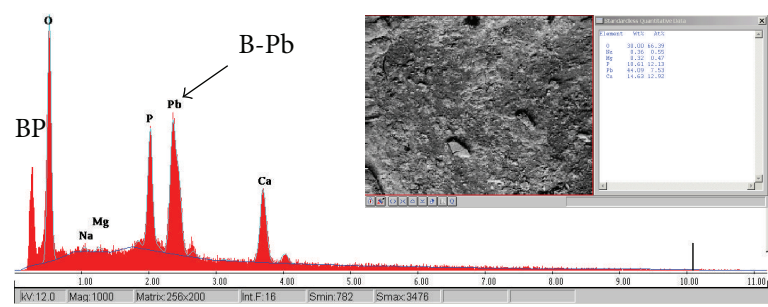

(b)

Figure 3: SEM-EDX spectrum of (a) B and (b) B-Pb.
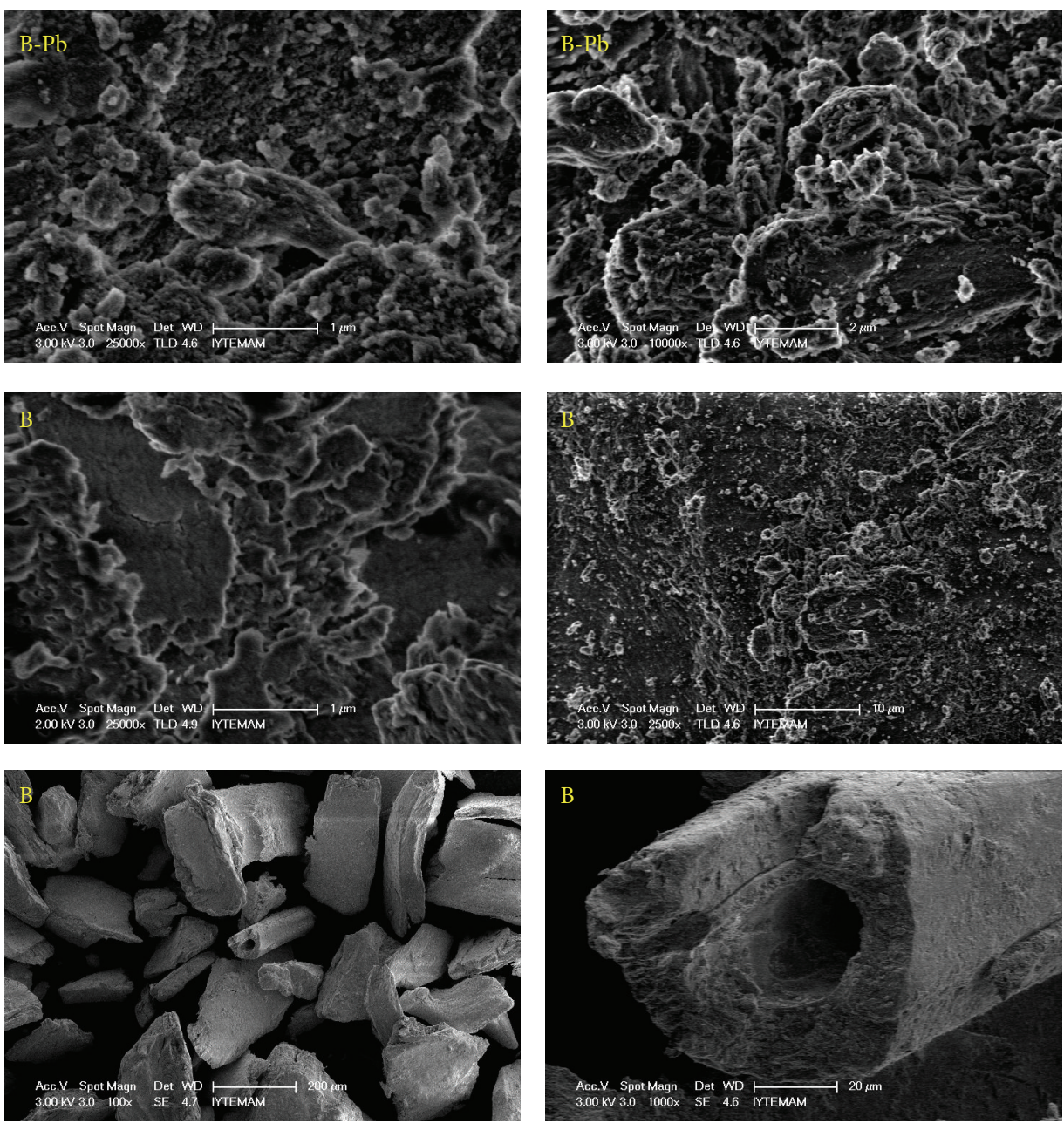

FIgURE 4: SEM images (1-2 $\mu \mathrm{m})$ of (a) B-Pb and B.

SEM images of $\mathrm{B}-\mathrm{Pb}$ clearly show that the bone surfaces with adsorbed $\mathrm{Pb}$ (II) are rough compared with surfaces of B. After the adsorption of metal ions from the aqueous solutions the surfaces of bone sorbents were changed. The change in the surfaces could be explained by the reaction $(b)$. Based on this reaction, it could be said that very small HAP particles $(<1 \mu \mathrm{m})$ were attached to the surfaces of bone sorbents by ion exchange between trivalent $\mathrm{Pb}$ metal ions and $-\mathrm{ONa}$ of HAP [20].

The DTA/TG analysis of $\mathrm{B}$ and $\mathrm{B}-\mathrm{Pb}$ is shown in Table 3 . The DTA/TGA analysis shows that B and B-Pb have $69.88 \%$ and $74.55 \%$ inorganic residue amount (RA) with mono weight losses at $800^{\circ} \mathrm{C}$, respectively. The weight losses of $10 \%$ for $\mathrm{B}$ and $\mathrm{B}-\mathrm{Pb}$ were found to be $328^{\circ} \mathrm{C}$ and $336^{\circ} \mathrm{C}$, 
TABLE 2: Element compositions and Ca/P mole ratios of fish bones by SEM-EDX.

\begin{tabular}{lccccccccc}
\hline Element $(\mathrm{wt} \%)$ & $\mathrm{Ca}$ & $\mathrm{P}$ & $\mathrm{Na}$ & $\mathrm{Mg}$ & $\mathrm{K}$ & $\mathrm{O}$ & $\mathrm{Pb}$ & $\mathrm{Ca} / \mathrm{P}$ & $\mathrm{Total} w \mathrm{t} \%$ \\
\hline $\mathrm{B}$ & 36.44 & 17.57 & 1.36 & 0.98 & 0.57 & 43.08 & - & 1.60 & 100 \\
${ }^{*} \mathrm{~B}-\mathrm{Pb}$ & 14.63 & 10.61 & 0.36 & 0.32 & - & 30.00 & 44.09 & 1.06 & 100 \\
\hline
\end{tabular}

${ }^{*}$ Adsorbed $\mathrm{Pb}$ of the $\mathrm{B}_{\mathrm{BBB}}$ sorbent.

TABLE 3: DTA/TG results of B and B-Pb.

\begin{tabular}{lcccccrr}
\hline & & \multicolumn{3}{c}{ TGA } & \multicolumn{3}{c}{ DTA } \\
& $D_{1}\left({ }^{\circ} \mathrm{C}\right)$ & $D_{2}\left({ }^{\circ} \mathrm{C}\right)$ & $D_{3}(25 \%)\left({ }^{\circ} \mathrm{C}\right)$ & $D_{4}(10 \%)\left({ }^{\circ} \mathrm{C}\right)$ & $\mathrm{RA}($ wt $\%)$ at $800^{\circ} \mathrm{C}$ & Exo. & Endo. \\
\hline $\mathrm{B}$ & 211 & 352 & 508 & 328 & 69.88 & 392 & - \\
$\mathrm{B}-\mathrm{Pb}$ & 207 & 354 & 775 & 336 & 74.55 & 390 \\
\hline
\end{tabular}

$D_{1}$ : the starting temperature of degradation; $D_{2}$ : maximum degradation temperature; $D_{3}$ and $D_{4}$ : weight losses with 25 and 10 wt $\%$; RA: residue amount (wt $\%$ ); Exo.: exothermic; Endo.: endothermic.

respectively. The maximum degradation temperatures $\left(D_{2}\right)$ of $\mathrm{B}$ and $\mathrm{B}-\mathrm{Pb}$ were calculated as $352^{\circ} \mathrm{C}$ and $354^{\circ} \mathrm{C}$, respectively.

3.2. Effect of $\mathrm{pH}$. The effect of $\mathrm{pH}$ on the adsorption of $\mathrm{Pb}$ (II) on the pretreated fish bones $\mathrm{B}$ was studied in the $\mathrm{pH}$ range of 3 and 5.5 at $780 \mathrm{mg} / \mathrm{L}$ of initial metal concentration. The initial $\mathrm{pH}$ values were adjusted by adding diluted $\mathrm{HNO}_{3}$ and $\mathrm{NaOH}$ solutions. The results are shown in Figure 5 and Table 4 . Since HAP, the main constituent of the fish bones, starts to dissolve at $\mathrm{pH}$ lower than 3 , the initial $\mathrm{pH}$ was chosen to be 3 [11]. The $\mathrm{pH}$ values higher than 5.5 were not studied because the precipitation of lead ions as lead hydroxides occurs at high concentrations [26]. In this study, a number of kinetic, temperature, $\mathrm{pH}$, and time experiments were carried out on high lead concentrations (like $2000 \mathrm{mg} / \mathrm{L}$ lead (II) solutions) and therefore, the selected $\mathrm{pH}$ value of 5 was chosen in order to prevent the formation of lead hydroxides and to get comparable results at standard $\mathrm{pH}$. $\mathrm{pH} 5$ was selected instead of $\mathrm{pH} 3$, because this $\mathrm{pH}$ is close to natural water.

Figure 5 demonstrates that the adsorption capacity for $\mathrm{Pb}$ (II) increased with increasing $\mathrm{pH}$. The highest adsorption capacity was found to be $118.7 \mathrm{mg} / \mathrm{g}$ at $\mathrm{pH} 5.5$ and the results of lead removal capacities at different $\mathrm{pH}$ values are given in Table 4. The effect of $\mathrm{pH}$ plays an important role in the phosphate and hydroxyl groups of HAP during the cationexchange reaction on the bone surface. At lower $\mathrm{pH}, \mathrm{HAP}$ is dissolved and protons compete with metal ions for a binding site. The concentration of protons at lower $\mathrm{pH}$ is higher; thus, more groups are bound with protons and therefore fewer groups are available for metal ions to bind with [27].

3.3. Kinetic Study. The modeling of the kinetics of adsorption of $\mathrm{Pb}$ (II) using $\mathrm{B}_{\mathrm{BBB}}$ was investigated by using two common models: pseudo-first and second-order kinetic equations. The Lagergren equation was used for the pseudo-first-order equation (2) [28, 29]:

$$
\ln \left(q_{e}-q_{t}\right)=\ln q_{e, \mathrm{cal}}-k_{1} \cdot t,
$$

where $k_{1}$ is the rate constant of pseudo-first-order sorption $\left(\mathrm{h}^{-1}\right)$ and $q_{e}$ and $q_{t}$ are the amounts of metal adsorbed per gram of fish bone ( $\mathrm{mg} / \mathrm{g}$ bone) at equilibrium and any time, respectively. The plot of $\ln \left(q_{e}-q_{t}\right)$ versus $t$ for pseudofirst-order kinetics showed a linear relationship. The slope and intercept of $\ln \left(q_{e}-q_{t}\right)$ versus $t$ were used to calculate the pseudo-first-order rate constant $k_{1}$ and $q_{e, \text { cal }}$, shown in Table 5. Equation (3) was used for the pseudo-second-order kinetic model $[30,31]$ :

$$
\frac{t}{q_{t}}=\frac{1}{k_{2} q_{e, \mathrm{cal}}^{2}}+\frac{t}{q_{e, \mathrm{cal}}}
$$

where $k_{2}$ (g bone/mg hour) is the rate constant for pseudosecond-order adsorption. The constants $q_{e \text {,cal }}$ and $k_{2}$ values were calculated from the slopes and intercepts of $t / q_{t}$ versus $t$ plots. $h_{i}$ value was calculated using $k_{2}$ rate constant obtained from pseudo-second-order kinetic data and expressed as

$$
h_{i}=k_{2} q_{e, \text { cal }}^{2} \text {, }
$$

where the value of $h_{i}$ is the initial metal adsorption rate $(\mathrm{mg} / \mathrm{g}$ bone hour) [32]. The constants $k_{2}, q_{e, \text { cal }}$, and $h$ were calculated from the intercept and slope of the line obtained by plotting $t / q_{t}$ against $t$ and are shown in Table 5 .

The kinetic data obtained from $\mathrm{Pb}$ (II) adsorption experiments were analyzed using the pseudo-first-order kinetic model according to (2) and the results are given in Table 5. Maximum rate constants $k_{1}$ were determined at a temperature of $30^{\circ} \mathrm{C}$. The calculated adsorption values $\left(q_{e, \text { cal }}\right)$ are not supported by the experimental data $\left(q_{e, \text { cal }}\right)$. The highest $k_{2}$ values at different temperatures and concentrations were found to be $2.13 \mathrm{~g} / \mathrm{mg} \cdot \mathrm{h}$ and $3.76 \times 10^{-3} \mathrm{~g} / \mathrm{mg} \cdot \mathrm{h}$ at $50^{\circ} \mathrm{C}$ and $417 \mathrm{mg} / \mathrm{L}$, respectively. The effect of time on the adsorption capacity for $\mathrm{Pb}$ (II) at different temperatures is given in Figure 6.

According to Table 5, the correlation coefficients $\left(R^{2}\right)$ of the pseudo-second-order kinetic model for the linear plots are higher than 0.99 for all the temperatures and concentrations. On the other hand, when $R$ values of the pseudo-second-order kinetic model are calculated from the $R^{2}$ values, it is clearly shown that $R$ values for all the temperatures and concentrations are higher than 0.9999 and at the same time are higher than the $R$ values of the pseudofirst-order kinetic model. The calculated $\left(q_{e, \text { cal }}\right)$ adsorption amount for the pseudo second-order kinetic model is close to 
TABLE 4: Results of lead removal capacities at different pHs.

\begin{tabular}{lcccc}
\hline $782 \mathrm{mg} \mathrm{Pb}{ }^{+2} / \mathrm{L}$ & \multicolumn{3}{c}{$\mathrm{pH}$} & 5 \\
$20^{\circ} \mathrm{C}$ & 3 & 4 & $117.45 \pm 1.92$ & $118.79 \pm 1.90$ \\
\hline$q_{e, \text { exp }}(\mathrm{mg} / \mathrm{g}) \pm \mathrm{SEM}^{*}$ & $112.36 \pm 2.13$ & $116.00 \pm 1.98$ & 60.03 & 60.72 \\
$\%$ Removal & 57.43 & 59.29 & & \\
\hline
\end{tabular}

${ }^{*}$ SEM: standard error of the means $(n=3)$.

TABle 5: Pseudo-first and second-order kinetic constants of $\mathrm{Pb}$ (II) at different temperatures and concentrations.

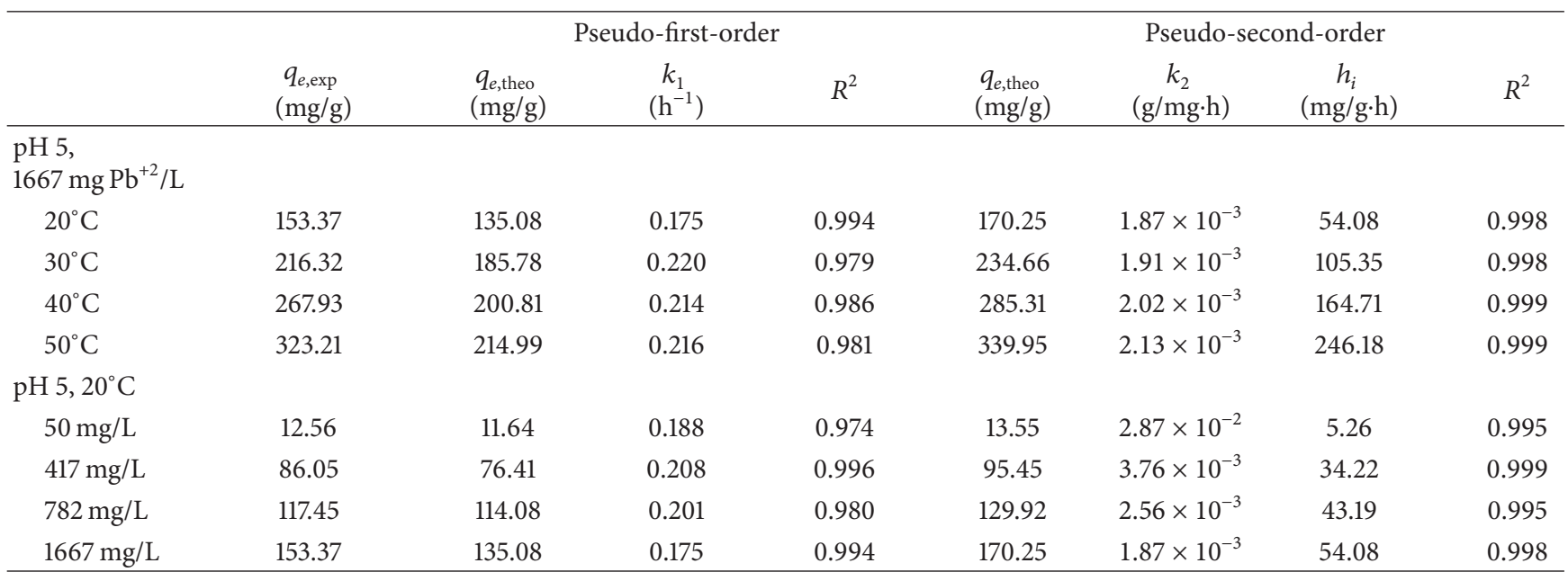

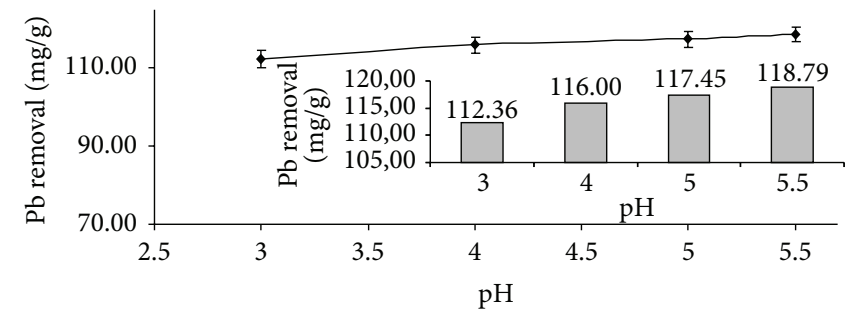

Figure 5: The effect of $\mathrm{pH}$ on the adsorption of $\mathrm{Pb}$.

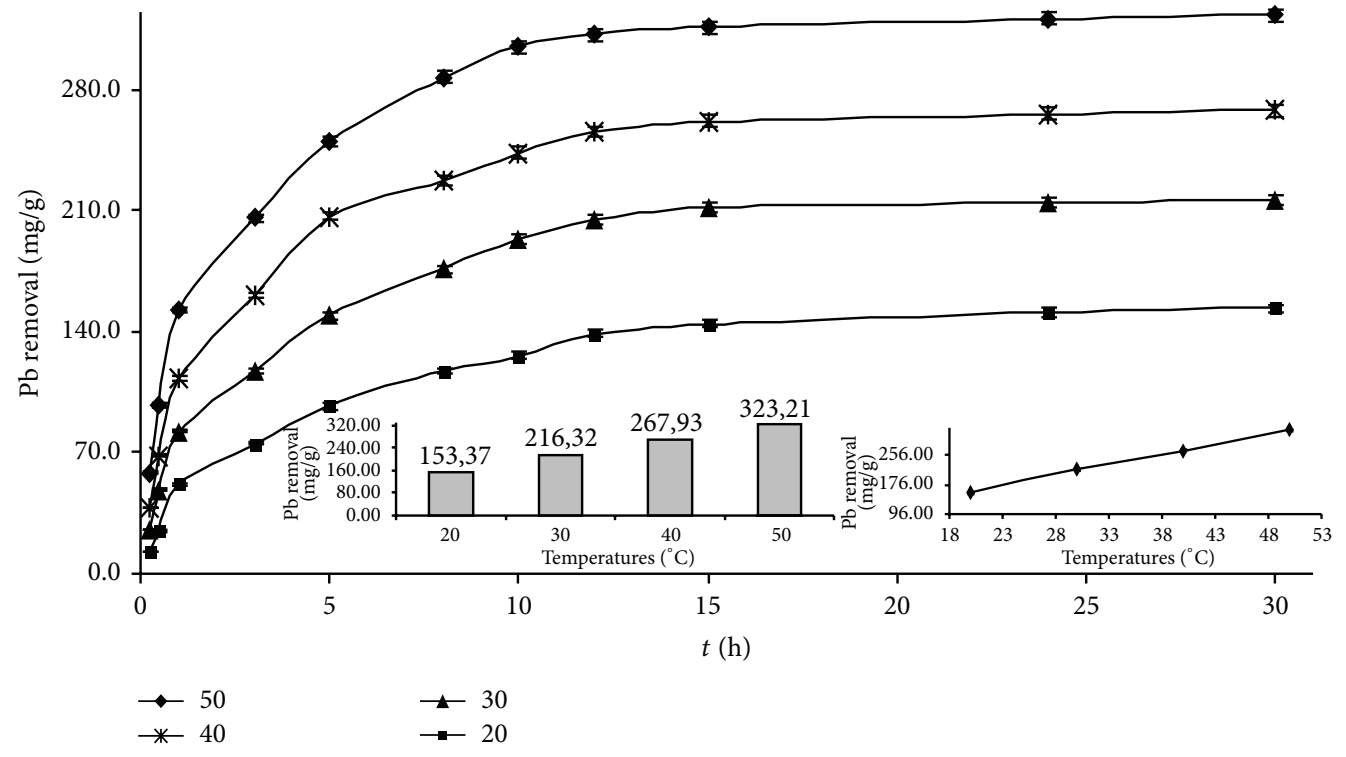

FIgURE 6: The effect of contact time and temperature on the adsorption of $\mathrm{Pb}$ (II). 
TABLE 6: Diffusion constants of $\mathrm{Pb}$ (II) at different temperatures and concentrations.

\begin{tabular}{|c|c|c|c|c|c|c|}
\hline & \multicolumn{2}{|c|}{ Urano and Tachikawa } & \multicolumn{4}{|c|}{ Weber and Morris } \\
\hline & $D_{i}\left(\mathrm{~m}^{2} \mathrm{~h}^{-1}\right)$ & $R^{2}$ & $\begin{array}{c}K_{w} \\
\left(\mathrm{mgg}^{-1} \mathrm{~h}^{-0.5}\right)\end{array}$ & $\begin{array}{c}C \\
(\mathrm{mg} / \mathrm{g})\end{array}$ & $\begin{array}{c}D_{w} \\
\left(\mathrm{~m}^{2} \mathrm{~h}^{-1}\right)\end{array}$ & $R^{2}$ \\
\hline \multicolumn{7}{|c|}{$\begin{array}{l}\text { pH 5, } \\
1667 \mathrm{mg} \mathrm{Pb}^{+2} / \mathrm{L}\end{array}$} \\
\hline $20^{\circ} \mathrm{C}$ & $2.61 \times 10^{-11}$ & 0.991 & 38.93 & 3.32 & $2.34 \times 10^{-13}$ & 0.979 \\
\hline $30^{\circ} \mathrm{C}$ & $5.00 \times 10^{-11}$ & 0.974 & 55.06 & 15.13 & $2.35 \times 10^{-13}$ & 0.976 \\
\hline $40^{\circ} \mathrm{C}$ & $4.88 \times 10^{-11}$ & 0.990 & 65.83 & 32.47 & $2.19 \times 10^{-13}$ & 0.951 \\
\hline $50^{\circ} \mathrm{C}$ & $4.98 \times 10^{-11}$ & 0.990 & 75.73 & 56.45 & $1.99 \times 10^{-13}$ & 0.943 \\
\hline \multicolumn{7}{|l|}{$\mathrm{pH} 5,20^{\circ} \mathrm{C}$} \\
\hline $50 \mathrm{mg} / \mathrm{L}$ & $4.19 \times 10^{-11}$ & 0.949 & 2.87 & 1.19 & $1.89 \times 10^{-13}$ & 0.962 \\
\hline $417 \mathrm{mg} / \mathrm{L}$ & $4.66 \times 10^{-11}$ & 0.991 & 23.13 & 1.60 & $2.62 \times 10^{-13}$ & 0.962 \\
\hline $782 \mathrm{mg} / \mathrm{L}$ & $4.47 \times 10^{-11}$ & 0.962 & 29.56 & 3.23 & $2.30 \times 10^{-13}$ & 0.993 \\
\hline $1667 \mathrm{mg} / \mathrm{L}$ & $2.61 \times 10^{-11}$ & 0.991 & 38.93 & 3.32 & $2.34 \times 10^{-13}$ & 0.979 \\
\hline
\end{tabular}

the experimental data $\left(q_{e, \text { exp }}\right)$, but $q_{e, \text { cal }}$ for the pseudo-firstorder kinetic model are generally not supported by $q_{e, \text { exp }}$. The correlation coefficients of the pseudo-second-order kinetic model for the linear plots are higher than 0.99 for all the temperatures and concentrations. According to the correlation coefficient constant $\left(R^{2}\right)$ and the experimental adsorption amount $\left(q_{e, \text { exp }}\right)$, it could be said that the experimental data exhibit a good compliance with the pseudo second-order equation for $\mathrm{Pb}$ (II) removal. Similar kinetic applications were also determined for Co (II) removal with animal bone [11], in which the adsorption rate of Co (II) ions on the animal bones was described by a second-order rate expression; the pseudosecond-order model correlates well with the experimental data on the sorption of divalent and trivalent metal cations by synthetic HAP [33].

3.4. Diffusion Parameters. The intraparticle diffusion model (IPD) of Weber and Morris has been widely applied to the analysis of adsorption kinetics [34]. Weber-Morris and Urano-Tachikawa modeling were used to model the diffusion of $\mathrm{Pb}$ (II) from aqueous solution using $\mathrm{B}_{\mathrm{BBB}}$. $35,36]$

The Weber and Morris diffusion model is expressed as [15,

$$
q_{t}=K w \cdot t^{0.5}+C
$$

In this equation, $K w\left(\mathrm{mg} \cdot \mathrm{g}^{-1} \mathrm{~h}^{-0.5}\right)$ is the Weber and Morris intraparticle diffusion rate constant and $C$ is a value of intercept constant of the plot that provide information about thickness of the boundary layer $(\mathrm{mg} / \mathrm{g})$. The value of $q_{t}$ (the amount of adsorption at any time) is plotted against $t^{0.5}$ (the square root of time) to get a straight line. The intraparticle diffusion constant $(K w)$ was calculated from the slopes of $q_{t}$ versus $t^{0.5}$ plots.

The intraparticle diffusion coefficient $(D w)$ was calculated using $[37,38]$

$$
D w=\left(\frac{\pi}{8640}\right)\left(\frac{d K w}{q_{e}}\right)^{2},
$$

where $D w\left(\mathrm{~m}^{2} \mathrm{~h}^{-1}\right)$ is the diffusion coefficient in the solid and $d(\mathrm{~m})$ is the mean particle diameter.

The following equation (7) was used for the intraparticle diffusion model of Urano and Tachikawa [37, 39]:

$$
-\log \left[1-\left(\frac{q_{t}}{q_{e}}\right)^{2}\right]=4 \pi^{2} \frac{D_{i} t}{2.3 d^{2}}
$$

where $D_{i}$ was calculated from the slopes of $-\log \left[1-\left(q / q_{e}\right)^{2}\right]$ versus $t$ plots.

The values of $K w, D w, D_{i}$, and $C$ are given in Table 6 . The highest $D_{i}$ values for the Urano and Tachikawa model were found to be $5.00 \mathrm{~m}^{2} \mathrm{~h}^{-1}$ at $30^{\circ} \mathrm{C}$. The maximum $\mathrm{Kw}$ values according to the Weber and Morris model were found to be $75.7 \mathrm{mg} \mathrm{g}^{-1} \mathrm{~h}^{-0.5}$ at $50^{\circ} \mathrm{C}$. The constant $C$ increased with the increase in temperature from $20^{\circ} \mathrm{C}$ to $50^{\circ} \mathrm{C}$ and likewise increased with the increase in concentration. The value of the intercepts of the plot of $t^{0.5}$ versus $q_{e}$ and the constant $C$ from (5) provide information about the boundary layer effect for the Weber and Morris model. An increase in the value of constant $C$ indicates the abundance of solute adsorbed by the boundary effect [36]. Our results were similar to the research of Bilgili [40], who reported that $K w$ values decreased and $C$ values increased with increasing temperatures. $D w$ was found to decrease from $2.34 \mathrm{~m}^{2} \mathrm{~h}^{-1}$ to $1.99 \times 10^{-13} \mathrm{~m}^{2} \mathrm{~h}^{-1}$ with an increase in temperature from $20^{\circ} \mathrm{C}$ to $50^{\circ} \mathrm{C}$ except for at $30^{\circ} \mathrm{C}$, respectively. On the other hand, $D w$ was found to increase from $1.89 \mathrm{~m}^{2} \mathrm{~h}^{-1}$ to $2.34 \times 10^{-13} \mathrm{~m}^{2} \mathrm{~h}^{-1}$ with an increase in concentration from $50 \mathrm{mg} / \mathrm{L}$ to $1667 \mathrm{mg} / \mathrm{L}$ except for at $417 \mathrm{mg} / \mathrm{L}$, respectively. According to Greluk and Hubicki [36], if the intraparticle diffusion $K w$ is involved in the adsorption process, then the plot of $t^{0.5}$ versus $q_{e}$ would result in a linear graph and the process of intraparticle diffusion would be the controlling step if this line passed through the origin. When the data exhibit multilinear plots which do not pass through the origin, this is indicative of some degree of boundary layer control and further shows that intraparticle diffusion is not the only rate-controlling factor, but that other processes may control the rate of sorption [36]. 
TABLE 7: Results of removal capacities at different temperatures and thermodynamic constants of $\mathrm{Pb}$ (II).

\begin{tabular}{|c|c|c|c|c|c|c|}
\hline \multirow{2}{*}{$\begin{array}{l}\text { pH 5, } \\
1667 \mathrm{mg} \mathrm{Pb}^{+2} / \mathrm{L}\end{array}$} & \multicolumn{6}{|c|}{ Temperatures $\left({ }^{\circ} \mathrm{C}\right)$} \\
\hline & 20 & \multicolumn{2}{|c|}{30} & \multicolumn{2}{|c|}{40} & 50 \\
\hline$q_{e, \exp }(\mathrm{mg} / \mathrm{g}) \pm \mathrm{SEM}^{*}$ & $153.37 \pm 2.53$ & \multicolumn{2}{|c|}{$216.32 \pm 2.90$} & \multicolumn{2}{|c|}{$267.93 \pm 3.24$} & $323.21 \pm 3.65$ \\
\hline$\%$ Removal & 36.80 & \multicolumn{2}{|c|}{51.90} & \multicolumn{2}{|c|}{64.29} & 77.55 \\
\hline \multirow{2}{*}{$\Delta H^{\circ}\left(\mathrm{KJ} \mathrm{mol}^{-1}\right)$} & \multirow{2}{*}{$\Delta S^{\circ}\left(\mathrm{KJ} \mathrm{mol}^{-1} \mathrm{~K}^{-1}\right)$} & \multicolumn{4}{|c|}{$\Delta G^{\circ}\left(\mathrm{KJ} \mathrm{mol}^{-1}\right)$} & $E_{a}$ \\
\hline & & $20^{\circ} \mathrm{C}$ & $30^{\circ} \mathrm{C}$ & $40^{\circ} \mathrm{C}$ & $50^{\circ} \mathrm{C}$ & $\left(\mathrm{KJ} \mathrm{mol}^{-1}\right)$ \\
\hline 46.01 & 0.141 & 4.73 & 3.32 & 1.91 & 0.50 & 7.06 \\
\hline
\end{tabular}

${ }^{*}$ SEM: standard error of the means $(n=3)$.

The values of $D_{i}$ and $D w$ are different from each other and the Weber and Morris model gives lower diffusion coefficients than the Urano and Tachikawa model. Generally, Table 6 shows that $R^{2}$ values and intraparticle diffusion of the Urano and Tachikawa model were better than those of the Weber and Morris model. Thus, it can be concluded that the experimental data for the intraparticle diffusion model of $\mathrm{Pb}$ (II) on the bone sorbents fit the Urano and Tachikawa model.

3.5. Temperatures and Thermodynamic Parameters. The activation energy $\left(E_{a}\right)$ for the adsorption of $\mathrm{Pb}$ (II) was determined using the Arrhenius equation and is expressed as [29]

$$
\ln k=\ln A-\frac{E_{a}}{R T}
$$

where $k$ is the rate constant $k_{2}$ (pseudo-second-order) which was obtained from Table $3, E_{a}\left(\mathrm{~kJ} \mathrm{~mol}^{-1}\right), T(\mathrm{~K}), R$ $\left(\mathrm{kJ} \mathrm{mol}{ }^{-1} \mathrm{~K}^{-1}\right)$, and $A$ are the Arrhenius activation energy, temperature of the adsorption medium, the gas constant and the Arrhenius factor, respectively. The activation energy $E_{a}$ was calculated from the slope of the line obtained by plotting $\ln k$ against $1 / T$ and is shown in Table 4 .

The thermodynamic parameters known as Gibbs free energy $\left(\Delta G^{\circ}\right)$, enthalpy $\left(\Delta H^{\circ}\right)$, and entropy $\left(\Delta S^{\circ}\right)$ were determined by using the following equations $[32,41-43]$ :

$$
\begin{aligned}
K_{c} & =\frac{C_{a}}{C_{e}} \\
\Delta G^{\circ} & =\Delta H^{\circ}-T \Delta S^{\circ} \\
\ln K_{c} & =\frac{\Delta S^{\circ}}{R}-\frac{\Delta H^{\circ}}{R T},
\end{aligned}
$$

where $C_{a}$ and $C_{e}$ are the amount of metal ions ( $\mathrm{mg}$ ) adsorbed on the adsorbent per liter of the solution at equilibrium time and the equilibrium concentration $(\mathrm{mg} / \mathrm{L})$ of metal ions in the solution, respectively. The $K_{c}$ value is used in (11) to determine the thermodynamic parameters of adsorption. $T(K)$ and $R$ are the solution temperature and gas constant, respectively. The constants of $\Delta H^{\circ}$ and $\Delta S^{\circ}$ were calculated from the slope and intercept of van't Hoff plots of $\ln K_{c}$ versus $1 / T$. The free energy $\left(\Delta G^{\circ}\right)$ was calculated from (10) using $\Delta H^{\circ}$ and $\Delta S^{\circ}$. The results are shown in Table 4. The Gibbs free energy indicates the fundamental of spontaneity of the adsorption process. When $\Delta G^{\circ}$ is a negative quantity, the adsorption process occurs spontaneously and higher negative values reflect a more energetically favorable adsorption [42].

The values of $E_{a}, \Delta H^{\circ}$, and $\Delta S^{\circ}$ were found to be 7.06 , $46.01 \mathrm{~kJ} \mathrm{~mol}^{-1}$, and $0.141 \mathrm{~kJ} \mathrm{~mol}^{-1} \mathrm{~K}^{-1}$ for $\mathrm{Pb}$ (III), respectively (Table 7). The values of $\Delta G^{\circ}$ for the temperatures of $20^{\circ} \mathrm{C}, 30^{\circ} \mathrm{C}, 40^{\circ} \mathrm{C}$, and $50^{\circ} \mathrm{C}$ were found to be $4.73 \mathrm{~kJ} \mathrm{~mol}^{-1}$, $3.32 \mathrm{~kJ} \mathrm{~mol}^{-1}, 1.91 \mathrm{~kJ} \mathrm{~mol}^{-1}$, and $0.50 \mathrm{~kJ} \mathrm{~mol}^{-1}$, respectively. According to Şeker et al. [30], if the value of $E_{a}$ is between $8.4 \mathrm{~kJ} \mathrm{~mol}^{-1}$ and $83.7 \mathrm{~kJ} \mathrm{~mol}^{-1}$, the adsorption is said to be chemical type and the rate constant changes with temperature according to the activation energy in the Arrhenius equation (8). The positive values of $\Delta G^{\circ}$ at temperatures lower than $55^{\circ} \mathrm{C}(328 \mathrm{~K})$ show that the adsorption of $\mathrm{Pb}$ (II) ions onto the fish bonesis nonspontaneous; in other words the adsorption process requires higher temperatures to occur. It could be explained that the ion exchange amounts of metal ions with calcium at the solid/liquid interface at low temperatures are lower than those at higher temperatures during the sorbates and sorbents interaction. When the temperature increased beyond $328 \mathrm{~K}\left(55^{\circ} \mathrm{C}\right)$, the $\Delta G^{\circ}$ values turned to negative. For example, the $\Delta G^{\circ}$ for $328 \mathrm{~K}\left(55^{\circ} \mathrm{C}\right)$ is calculated as $-0.238 \mathrm{~kJ} / \mathrm{mol}$. According to Lazarević et al. [44], this state points the presence of an energy barrier for the sorption process. The positive values of Gibbs free energy $\left(\Delta G^{\circ}\right)$ indicate that the adsorption process requires a small amount of energy with increasing temperature [44]. On the other hand, according to Zhou et al. [23], the decrease in $\Delta G^{\circ}$ with increasing temperature implies a greater driving force and more spontaneous adsorption at high temperature. Similar calculations of thermodynamic parameters were also determined for Ni (II) removal with Sepiolite by Lazarević et al. [44]. According to Lazarević et al. [44], enthalpy $\left(\Delta H^{\circ}\right)$ and entropy $\left(\Delta S^{\circ}\right)$ for $\mathrm{Ni}$ (II) removal with sepiolite were found to be $27.93 \mathrm{~kJ} / \mathrm{mol}$ and $0.0767 \mathrm{~kJ} / \mathrm{mol} \mathrm{K}$, respectively, and the Gibbs free energy $\left(\Delta G^{\circ}\right)$ was found to decrease from $5.05 \mathrm{~kJ} / \mathrm{mol}$ at $25^{\circ} \mathrm{C}$ to $1.98 \mathrm{~kJ} / \mathrm{mol}$ at $65^{\circ} \mathrm{C}$. For the positive $\Delta G^{\circ}$, Lazarević et al. [44] have explained that "Considering the positive values of $\Delta G^{\circ}$, it has been suggested that this is quite common for the sorption of metal ions by the ion exchange mechanism, because an activated complex of a metal ion is formed with the sorbent in the excited state." On the other hand, the values of $\Delta H^{\circ} \Delta S^{\circ}$ and $\Delta G^{\circ}$ in the study of Gupta et al. [45] were found to be $4.519 \mathrm{~kJ} / \mathrm{mol}, 0.0491 \mathrm{~kJ} / \mathrm{mol}$ $\mathrm{K}$ and $4.519519 \mathrm{~kJ} / \mathrm{mol}$, respectively. In the studies of Guan et al. [46] and Bhaumik et al. [47] show that all values of $\Delta H^{\circ}$, $\Delta S^{\circ}$, and $\Delta G^{\circ}$ were determined as positive. The positive values 
TABLE 8: Removal capacities and adsorption isotherms constants of $\mathrm{Pb}$ (II) at different initial concentrations.

\begin{tabular}{|c|c|c|c|c|c|c|c|}
\hline \multirow{2}{*}{$\mathrm{pH} 5,20^{\circ} \mathrm{C}$} & \multicolumn{7}{|c|}{ Initial concentration $(\mathrm{mg} / \mathrm{L})$} \\
\hline & 50.92 & 240.81 & 417.46 & 782.52 & 1042.55 & 1667.09 & 2036.26 \\
\hline$q_{e, \exp }(\mathrm{mg} / \mathrm{g}) \pm \mathrm{SEM}^{*}$ & $12.56 \pm 0.20$ & $59.82 \pm 0.23$ & $86.05 \pm 1.53$ & $117.45 \pm 1.92$ & $129.98 \pm 2.22$ & $153.37 \pm 2.46$ & $155.66 \pm 2.53$ \\
\hline \% Removal & 98.66 & 99.35 & 82.45 & 60.03 & 49.87 & 36.80 & 30.58 \\
\hline \multicolumn{3}{|c|}{ Freundlich } & & \multicolumn{4}{|c|}{ Langmuir } \\
\hline$K_{F}$ & $n$ & $R^{2}$ & & $Q_{\max }(\mathrm{mg} / \mathrm{g})$ & $b(\mathrm{~L} / \mathrm{mg})$ & $R^{2}$ & $R_{L}$ \\
\hline 26.54 & 3.90 & 0.806 & & 158.51 & $2.03 \times 10^{-3}$ & 0.993 & 0.906 \\
\hline
\end{tabular}

${ }^{*}$ SEM: standard error of the means $(n=3)$.

of enthalpy $\left(\Delta H^{\circ}\right)$ show that the adsorption and removal of metal ions using bone sorbents are the endothermic case and the positive Gibbs' free energy $\left(\Delta G^{\circ}\right)$ values confirm that the adsorption process for $\mathrm{Pb}$ (II) ions requires heat to proceed. Entropy has been defined as the degree of randomness of systems and $\Delta S^{\circ}$ for $\mathrm{Pb}$ was found to be a positive value in our study. The positive values of entropy may be a result of some structural changes in the bone sorbent which result in increased electronegativity and decreased atomic volume (for $\mathrm{Pb}$ ) during the adsorption process between the metal and $\mathrm{Ca}^{2+}$ ions. The adsorption capacities at different temperatures are given in Table 7. The highest removal was found to be $323.2 \mathrm{mg} / \mathrm{g}$ at $50^{\circ} \mathrm{C}$.

3.6. Adsorption Isotherms. Adsorption isotherms are widely used as important criteria in optimizing the use of adsorbents because they describe the nature ofthe interaction between adsorbate and adsorbent [17]. Two isotherms were used to describe the experimental results for the adsorption process of $\mathrm{Pb}$ (II) ions on fish bone, namely, the Langmuir and the Freundlich adsorption isotherms.

The Langmuir adsorption model assumes that the adsorbent surface has a saturated monolayer of molecules and finite number of identical sites which shows homogeneous surfaces [48]. The Langmuir equation is given by $[49,50]$

$$
\frac{C_{e}}{q_{e}}=\frac{C_{e}}{Q_{\max }}+\frac{1}{Q_{\max } b},
$$

where $C_{e}(\mathrm{mg} / \mathrm{L})$ and $q_{e}(\mathrm{mg} / \mathrm{g})$ are the residual metal concentration in solution and the amount of the metal adsorbed on the sorbent at equilibrium, respectively. $Q_{\max }(\mathrm{mg} / \mathrm{g})$ is the maximum amount of the metal ions per unit weight of sorbent and $b$ is the Langmuir adsorption equilibrium constant related to the affinity between the sorbent and metal ions. For the calculation of the Langmuir adsorption equilibrium constant, the plot of $\left(C_{e} / q_{e}\right)$ versus $C_{e}$ showed a linear relationship. The constants $Q_{\max }$ and $b$ were calculated from the slope and intercept of the curve of $\left(C_{e} / q_{e}\right)$ versus $C_{e}$ and the obtained results are shown in Table 8 .

To determine whether the adsorption process was favourable or unfavourable for the Langmuir adsorption, $R_{L}$ was used, given in $[23,51,52]$

$$
R_{L}=\frac{1}{\left(1+b C_{0}\right)}
$$

where $C_{0}(\mathrm{mg} / \mathrm{L})$ and $b(\mathrm{~L} / \mathrm{mg})$ are initial metal concentration and Langmuir constant, respectively. The value of $R_{L}$ indicates the shape of the isotherm to be unfavorable $\left(R_{L}>1\right)$, linear $\left(R_{L}=1\right)$, favorable $\left(0<R_{L}<1\right)$, or irreversible $\left(R_{L}=0\right)$. The $R_{L}$ values between 0 and 1 indicate favorable adsorption [35].

The Freundlich equation is applicable to heterogeneous surfaces and multilayer adsorption [48]. The linear form of the Freundlich equation is given by following equation [53, 54]:

$$
\ln q_{e}=\ln K_{F}+\left(\frac{1}{n}\right) \ln C_{e},
$$

where $K_{F}$ and $n$ are the adsorption capacity of the sorbent and adsorption intensity, respectively. For calculation of Freundlich adsorption equilibrium constants, the plot of $\ln q_{e}$ versus $\ln C_{e}$ shows a linear relationship. The values of $K_{F}$ and $n$ are calculated from the intercept and slope of the plot of $\ln q_{e}$ versus $\ln C_{e}$ and the results are given in Table 8 .

The adsorption amounts depending on concentrations are shown in Figure 7. The constants $K_{F}, n$, and $R^{2}$ obtained from the Freundlich isotherm were found to be 26.5, 3.9, and 0.806 , respectively. Based on the calculated correlation coefficients $\left(R^{2}\right)$ for the Langmuir and Freundlich isotherms, it can be suggested that the experimental data for the adsorption of $\mathrm{Pb}$ (II) on the bones fit the Langmuir isotherm model. The value of $R_{L}$ was found to be 0.906 (Table 8 ). The calculated $R_{L}$ value indicated that the adsorption of $\mathrm{Pb}$ (II) ions on the fish bones was favorable $\mathrm{Pb}$ (II) concentration. The adsorption capacities at different concentrations are given in Table 8. The highest removal was found to be 155.6 at $2036 \mathrm{mg} / \mathrm{L}$. The lead removal capacities of various adsorbents given in the literature are summarized in Table 9. Table 9 clearly shows that pretreated fish bones appear to be very useful sorbent.

\section{Conclusion}

Fish bones, one of the most abundant fish-processing industry waste products, were investigated for lead removal. With many specific advantages such as low cost, easy availability, natural origin, and high adsorption capacity, fish waste products can be used as sorbents to remove heavy metal. In this study, fish bones which exhibited high sorption capacity were used as a natural sorbent to remove lead.

The highest removal capacity for $\mathrm{Pb}$ (II) was found to be $323 \mathrm{mg} / \mathrm{g}$ at $50^{\circ} \mathrm{C}$. The experiments showed that when $\mathrm{pH}$ 


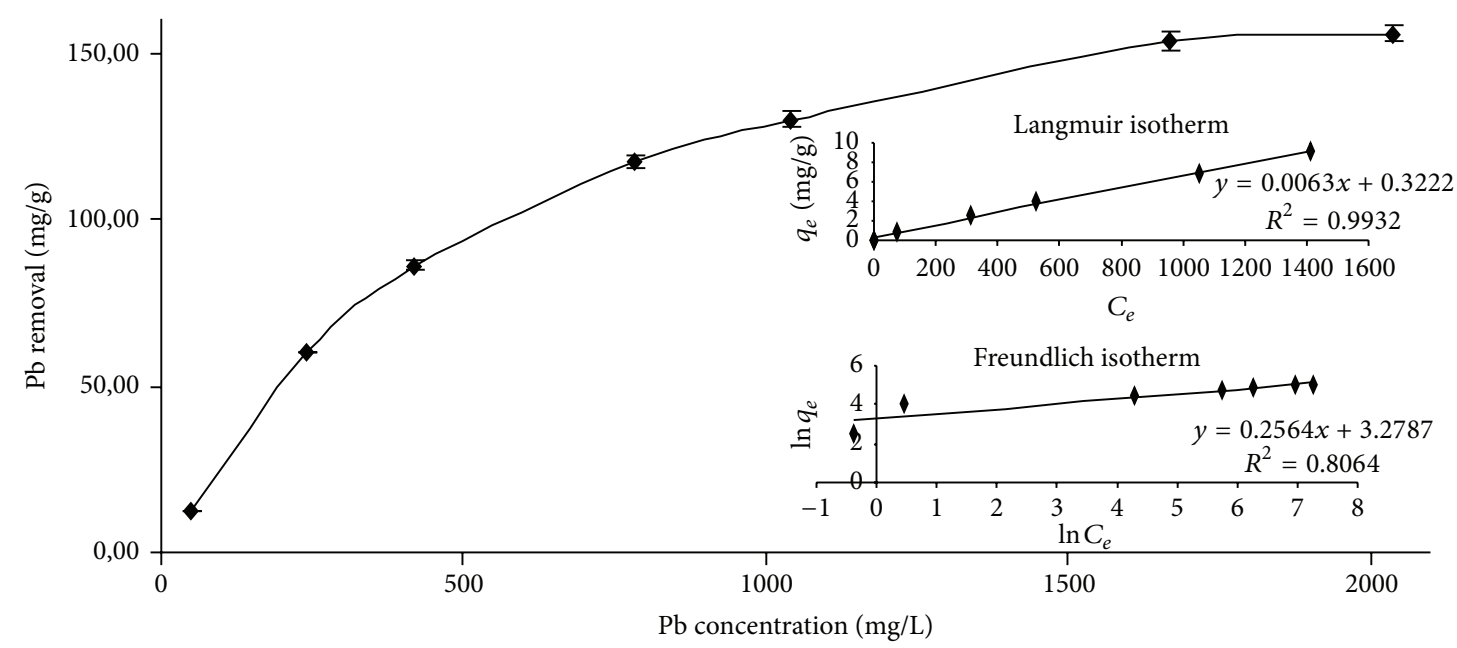

FIGURE 7: The effect of concentration on the adsorption of $\mathrm{Pb}$ (II).

TABLE 9: Comparison of lead removal with different adsorbents.

\begin{tabular}{lcc}
\hline Adsorbents & Removal capacity (mg/g) & Reference \\
\hline Pretreated fish bones & 323.21 & This study \\
Seaweed (Gymnogongrus Torulosus) & 140.89 & {$[17]$} \\
Algal biomass (Oedogonium sp. and Nostoc sp.) & 145.0 & [19] \\
Fruit shell (Mangostana) & 3.56 & {$[55]$} \\
Water hyacinth weed & 26.32 & {$[56]$} \\
Peels of banana & 2.18 & {$[57]$} \\
Saccharomyces cerevisiae biomass & 83.33 & {$[58]$} \\
\hline
\end{tabular}

increased, an increase in the adsorption capacity of the fish bones was observed. The correlation coefficients showed that the experimental data for the adsorption of $\mathrm{Pb}$ fitted well to the Langmuir isotherm model and the value of $R_{L}$ for $\mathrm{Pb}$ (II) was found to be 0.906 . The kinetic data fitted a pseudosecond-order kinetic model. The enthalpy $\Delta H^{\circ}$ of lead was calculated as $46.01 \mathrm{~kJ} \mathrm{~mol}^{-1}$ and the adsorption mechanism was endothermic. The activation energy, $E_{a}$ of adsorption of $\mathrm{Pb}(\mathrm{II})$, was determined as $7.06 \mathrm{~kJ} / \mathrm{mol}$. The experimental results showed that the correlation coefficients of intraparticle diffusion of the Urano and Tachikawa model were better than those of the Weber and Morris model. Desorption/leaching experiments showed that desorption of the $\mathrm{Pb}$ on the bone surface exhibited very low ratios. Fish bones can be used as adsorbent with simple processing. Therefore, the utilization of pretreated fish bones could be low cost and effective and might contribute to the protection of the environment.

\section{Conflict of Interests}

The authors declare that there is no conflict of interests regarding the publication of this paper.

\section{Acknowledgments}

The authors acknowledge the Scientific Research Project Commission of Canakkale Onsekiz Mart University (Project no: 2010/16) for financial support. The authors wish to thank the Central Laboratory of Canakkale Onsekiz Mart University.

\section{References}

[1] H. Kalavathy, B. Karthik, and L. R. Miranda, "Removal and recovery of $\mathrm{Ni}$ and $\mathrm{Zn}$ from aqueous solution using activated carbon from Hevea brasiliensis: batch and column studies," Colloids and Surfaces B: Biointerfaces, vol. 78, no. 2, pp. 291-302, 2010.

[2] P. H. Kansanen and J. Venetvaara, "Comparison of biological collectors of airborne heavy metals near ferrochrome and steel works," Water, Air, and Soil Pollution, vol. 60, no. 3-4, pp. 337359, 1991.

[3] E. Pip, "Cadmium, copper, and lead in soils and garden produce near a metal smelter at Flin Flon, Manitoba," Bulletin of Environmental Contamination and Toxicology, vol. 46, no. 5, pp. 790-796, 1991.

[4] H. Huang, G. Cheng, L. Chen, X. Zhu, and H. Xu, "Lead (II) removal from aqueous solution by spent agaricus bisporus: determination of optimum process condition using Taguchi method," Water, Air, and Soil Pollution, vol. 203, no. 1-4, pp. 5363, 2009.

[5] A. S. Özcan, Ö. Gök, and A. Özcan, "Adsorption of lead(II) ions onto 8-hydroxy quinoline-immobilized bentonite," Journal of Hazardous Materials, vol. 161, no. 1, pp. 499-509, 2009.

[6] H. Ghassabzadeh, M. Torab-Mostaedi, A. Mohaddespour, M. G. Maragheh, S. J. Ahmadi, and P. Zaheri, "Characterizations of Co 
(II) and $\mathrm{Pb}$ (II) removal process from aqueous solutions using expanded perlite," Desalination, vol. 261, no. 1-2, pp. 73-79, 2010.

[7] R. Donat, A. Akdogan, E. Erdem, and H. Cetisli, "Thermodynamics of $\mathrm{Pb}^{2+}$ and $\mathrm{Ni}^{2+}$ adsorption onto natural bentonite from aqueous solutions," Journal of Colloid and Interface Science, vol. 286, no. 1, pp. 43-52, 2005.

[8] S. E. Bailey, T. J. Olin, R. M. Bricka, and D. D. Adrian, "A review of potentially low-cost sorbents for heavy metals," Water Research, vol. 33, no. 11, pp. 2469-2479, 1999.

[9] A. Bhatnagar and A. K. Minocha, "Biosorption optimization of nickel removal from water using Punica granatum peel waste," Colloids and Surfaces B: Biointerfaces, vol. 76, no. 2, pp. 544-548, 2010.

[10] X.-F. Sun, C. Liu, Y. Ma, S.-G. Wang, B.-Y. Gao, and X.M. Li, "Enhanced $\mathrm{Cu}(\mathrm{II})$ and $\mathrm{Cr}(\mathrm{VI})$ biosorption capacity on poly(ethylenimine) grafted aerobic granular sludge," Colloids and Surfaces B: Biointerfaces, vol. 82, no. 2, pp. 456-462, 2011.

[11] S. Dimovic, I. Smiciklas, I. Plećaš, D. Antonovic, and M. Mitric, "Comparative study of differently treated animal bones for $\mathrm{Co}^{2+}$ removal," Journal of Hazardous Materials, vol. 164, no. 1, pp. 279-287, 2009.

[12] F. Banat, S. Al-Asheh, and F. Mohai, "Batch zinc removal from aqueous solution using dried animal bones," Separation and Purification Technology, vol. 21, no. 1-2, pp. 155-164, 2000.

[13] Y. Zhang, Y. Liu, X. Ji, C. E. Banks, and J. Song, "Flower-like agglomerates of hydroxyapatite crystals formed on an egg-shell membrane," Colloids and Surfaces B: Biointerfaces, vol. 82, no. 2, pp. 490-496, 2011.

[14] S. S. Baral, S. N. Das, G. R. Chaudhury, and P. Rath, "Adsorption of Cr (VI) by treated weed Salvinia cucullata: kinetics and mechanism," Adsorption, vol. 14, no. 1, pp. 111-121, 2008.

[15] A. El-Sikaily, A. El Nemr, A. Khaled, and O. Abdelwehab, "Removal of toxic chromium from wastewater using green alga Ulva lactuca and its activated carbon," Journal of Hazardous Materials, vol. 148, no. 1-2, pp. 216-228, 2007.

[16] J. R. Memon, S. Q. Memon, M. I. Bhanger, A. El-Turki, K. R. Hallam, and G. C. Allen, "Banana peel: a green and economical sorbent for the selective removal of $\mathrm{Cr}(\mathrm{VI})$ from industrial wastewater," Colloids and Surfaces B: Biointerfaces, vol. 70, no. 2, pp. 232-237, 2009.

[17] M. M. Areco and M. D. S. Afonso, "Copper, zinc, cadmium and lead biosorption by Gymnogongrus torulosus. Thermodynamics and kinetics studies," Colloids and Surfaces B: Biointerfaces, vol. 81, no. 2, pp. 620-628, 2010.

[18] K. S. Rao, S. Anand, and P. Venkateswarlu, "Adsorption of cadmium from aqueous solution by Ficus religiosa leaf powder and characterization of loaded biosorbent," CLEAN-Soil, Air, Water, vol. 39, no. 4, pp. 384-391, 2011.

[19] M. Z. Alam and S. Ahmad, "Chromium removal through biosorption and bioaccumulation by bacteria from tannery effluents contaminated soil," CLEAN-Soil, Air, Water, vol. 39, no. 3, pp. 226-237, 2011.

[20] B. Kizilkaya, A. A. Tekinay, and Y. Dilgin, "Adsorption and removal of $\mathrm{Cu}$ (II) ions from aqueous solution using pretreated fish bones," Desalination, vol. 264, no. 1-2, pp. 37-47, 2010.

[21] M. Ozawa, K. Satake, and R. Suzuki, "Removal of aqueous chromium by fish bone waste originated hydroxyapatite," Journal of Materials Science Letters, vol. 22, no. 7, pp. 513-514, 2003.

[22] I. Smičiklas, S. Dimović, I. Plećaš, and M. Mitrić, "Removal of $\mathrm{Co}^{2+}$ from aqueous solutions by hydroxyapatite," Water Research, vol. 40, no. 12, pp. 2267-2274, 2006.
[23] Y.-T. Zhou, C. Branford-White, H.-L. Nie, and L.-M. Zhu, "Adsorption mechanism of $\mathrm{Cu}^{2+}$ from aqueous solution by chitosan-coated magnetic nanoparticles modified with $\alpha$ ketoglutaric acid," Colloids and Surfaces B: Biointerfaces, vol. 74, no. 1, pp. 244-252, 2009.

[24] S. H. Jang, B. G. Min, Y. G. Jeong, W. S. Lyoo, and S. C. Lee, "Removal of lead ions in aqueous solution by hydroxyapatite/polyurethane composite foams," Journal of Hazardous Materials, vol. 152, no. 3, pp. 1285-1292, 2008.

[25] C. Stötzel, F. A. Müller, F. Reinert, F. Niederdraenk, J. E. Barralet, and U. Gbureck, "Ion adsorption behaviour of hydroxyapatite with different crystallinities," Colloids and Surfaces B: Biointerfaces, vol. 74, no. 1, pp. 91-95, 2009.

[26] I. Chaari, E. Fakhfakh, S. Chakroun et al., "Lead removal from aqueous solutions by a Tunisian smectitic clay," Journal of Hazardous Materials, vol. 156, no. 1-3, pp. 545-551, 2008.

[27] K. Chojnacka, "Biosorption of Cr(III) ions by eggshells," Journal of Hazardous Materials, vol. 121, no. 1-3, pp. 167-173, 2005.

[28] S. Chowdhury and P. Saha, "Adsorption kinetic modeling of safranin onto rice husk biomatrix using pseudo-first- and pseudo-second-order kinetic models: comparison of linear and non-linear methods," CLEAN-Soil, Air, Water, vol. 39, no. 3, pp. 274-282, 2011.

[29] Ç. Doğar, A. Gürses, M. Açıkyildiz, and E. Özkan, “Thermodynamics and kinetic studies of biosorption of a basic dye from aqueous solution using green algae Ulothrix sp.", Colloids and Surfaces B: Biointerfaces, vol. 76, no. 1, pp. 279-285, 2010.

[30] A. Şeker, T. Shahwan, A. E. Eroğlu, S. Yılmaz, Z. Demirel, and M. C. Dalay, "Equilibrium, thermodynamic and kinetic studies for the biosorption of aqueous lead(II), cadmium(II) and nickel(II) ions on Spirulina platensis," Journal of Hazardous Materials, vol. 154, no. 1-3, pp. 973-980, 2008.

[31] F. Granados-Correa, J. Vilchis-Granados, M. Jiménez-Reyes, and L. A. Quiroz-Granados, "Adsorption behaviour of La(III) and $\mathrm{Eu}(\mathrm{III})$ ions from aqueous solutions by hydroxyapatite: kinetic, isotherm, and thermodynamic studies," Journal of Chemistry, vol. 2013, Article ID 751696, 9 pages, 2013.

[32] M. S. Chiou and H. Y. Li, "Adsorption behavior of reactive dye in aqueous solution on chemical cross-linked chitosan beads," Chemosphere, vol. 50, no. 8, pp. 1095-1105, 2003.

[33] I. Smičiklas, A. Onjia, S. Raičević, Đ. Janaćković, and M. Mitrić, "Factors influencing the removal of divalent cations by hydroxyapatite," Journal of Hazardous Materials, vol. 152, no. 2, pp. 876-884, 2008.

[34] F.-C. Wu, R.-L. Tseng, and R.-S. Juang, "Initial behavior of intraparticle diffusion model used in the description of adsorption kinetics," Chemical Engineering Journal, vol. 153, no. 1-3, pp. 1-8, 2009.

[35] B. H. Hameed, J. M. Salman, and A. L. Ahmad, "Adsorption isotherm and kinetic modeling of 2,4-D pesticide on activated carbon derived from date stones," Journal of Hazardous Materials, vol. 163, no. 1, pp. 121-126, 2009.

[36] M. Greluk and Z. Hubicki, "Sorption of SPADNS azo dye on polystyrene anion exchangers: equilibrium and kinetic studies," Journal of Hazardous Materials, vol. 172, no. 1, pp. 289-297, 2009.

[37] O. M. M. Freitas, R. J. E. Martins, C. M. Delerue-Matos, and R. A. R. Boaventura, "Removal of $\mathrm{Cd}(\mathrm{II}), \mathrm{Zn}(\mathrm{II})$ and $\mathrm{Pb}(\mathrm{II})$ from aqueous solutions by brown marine macro algae: kinetic modelling," Journal of Hazardous Materials, vol. 153, no. 1-2, pp. 493-501, 2008.

[38] A. Selatnia, M. Z. Bakhti, A. Madani, L. Kertous, and Y. Mansouri, "Biosorption of $\mathrm{Cd}^{2+}$ from aqueous solution by a 
$\mathrm{NaOH}$-treated bacterial dead Streptomyces rimosus biomass," Hydrometallurgy, vol. 75, no. 1-4, pp. 11-24, 2004.

[39] K. Urano and H. Tachikawa, "Process development for removal and recovery of phosphorus from wastewater by a new adsorbent. II. Adsorption rates and breakthrough curves," Industrial \& Engineering Chemistry Research, vol. 30, no. 8, pp. 1897-1899, 1991.

[40] M. S. Bilgili, "Adsorption of 4-chlorophenol from aqueous solutions by xad- 4 resin: isotherm, kinetic, and thermodynamic analysis," Journal of Hazardous Materials, vol. 137, no. 1, pp. 157164, 2006

[41] R. Aravindhan, J. R. Rao, and B. U. Nair, "Removal of basic yellow dye from aqueous solution by sorption on green alga Caulerpa scalpelliformis," Journal of Hazardous Materials, vol. 142, no. 1-2, pp. 68-76, 2007.

[42] Z. Aksu, "Determination of the equilibrium, kinetic and thermodynamic parameters of the batch biosorption of nickel(II) ions onto Chlorella vulgaris," Process Biochemistry, vol. 38, no. 1, pp. 89-99, 2002.

[43] A. Babarinde, J. O. Babalola, J. Adegoke et al., "Biosorption of $\mathrm{Ni}(\mathrm{II}), \mathrm{Cr}(\mathrm{III})$, and $\mathrm{Co}(\mathrm{II})$ from solutions using Acalypha hispida leaf: kinetics, equilibrium, and thermodynamics," Journal of Chemistry, vol. 2013, Article ID 460635, 8 pages, 2013.

[44] S. Lazarević, I. Janković-Častvan, V. Djokić, Z. Radovanović, D. Janaćković, and R. Petrović, "Iron-modified sepiolite for $\mathrm{Ni}^{2+}$ sorption from aqueous solution: an equilibrium, kinetic, and thermodynamic study," Journal of Chemical \& Engineering Data, vol. 55, no. 12, pp. 5681-5689, 2010.

[45] V. K. Gupta, R. Jain, T. A. Saleh, A. Nayak, S. Malathi, and S. Agarwal, "Equilibrium and thermodynamic studies on the removal and recovery of Safranine-T dye from industrial effluents," Separation Science and Technology, vol. 46, no. 5, pp. 839-846, 2011.

[46] W. Guan, J. Pan, H. Ou et al., "Removal of strontium(II) ions by potassium tetratitanate whisker and sodium trititanate whisker from aqueous solution: equilibrium, kinetics and thermodynamics," Chemical Engineering Journal, vol. 167, no. 1, pp. 215222, 2011.

[47] M. Bhaumik, T. Y. Leswifi, A. Maity, V. V. Srinivasu, and M. S. Onyango, "Removal of fluoride from aqueous solution by polypyrrole $/ \mathrm{F}_{3} \mathrm{O}_{4}$ magnetic nanocomposite," Journal of Hazardous Materials, vol. 186, no. 1, pp. 150-159, 2011.

[48] M. Chiban, A. Soudani, F. Sinan, and M. Persin, "Single, binary and multi-component adsorption of some anions and heavy metals on environmentally friendly Carpobrotus edulis plant," Colloids and Surfaces B: Biointerfaces, vol. 82, no. 2, pp. 267-276, 2011.

[49] I. Langmuir, "The adsorption of gases on plane surfaces of glass, mica and platinum," Journal of the American Chemical Society, vol. 40, no. 9, pp. 1361-1403, 1918.

[50] Ü. Geçgel, G. Özcan, and G. Ç. Gürpınar, "Removal of methylene blue from aqueous solution by activated carbon prepared from pea shells (Pisum sativum)," Journal of Chemistry, vol. 2013, Article ID 614083, 9 pages, 2013.

[51] A. Rafique, M. A. Awan, A. Wasti, I. A. Qazi, and M. Arshad, "Removal of fluoride from drinking water using modified immobilized activated alumina," Journal of Chemistry, vol. 2013, Article ID 386476, 7 pages, 2013.

[52] S. S. Majumdar, S. K. Das, R. Chakravarty, T. Saha, T. S. Bandyopadhyay, and A. K. Guha, "A study on lead adsorption by Mucor rouxii biomass," Desalination, vol. 251, no. 1-3, pp. 96102, 2010.
[53] N. Y. Mezenner, A. Hamadi, S. Kaddour, Z. Bensaadi, and A. Bensmaili, "Biosorption behavior of basic red 46 and violet 3 by dead Pleurotus mutilus from single- and multicomponent systems," Journal of Chemistry, vol. 2013, Article ID 965041, 12 pages, 2013.

[54] T. Shanthi and V. M. Selvarajan, "Removal of $\mathrm{Cr}(\mathrm{VI})$ and $\mathrm{Cu}(\mathrm{II})$ ions from aqueous solution by carbon prepared from Henna leaves," Journal of Chemistry, vol. 2013, Article ID 304970, 6 pages, 2013.

[55] R. Zein, R. Suhaili, F. Earnestly, I. Indrawati, and E. Munaf, "Removal of $\mathrm{Pb}(\mathrm{II}), \mathrm{Cd}(\mathrm{II})$ and $\mathrm{Co}(\mathrm{II})$ from aqueous solution using Garcinia mangostana L. fruit shell," Journal of Hazardous Materials, vol. 181, no. 1-3, pp. 52-56, 2010.

[56] C. Mahamadi and T. Nharingo, "Utilization of water hyacinth weed (Eichhornia crassipes) for the removal of $\mathrm{Pb}(\mathrm{II}), \mathrm{Cd}(\mathrm{II})$ and $\mathrm{Zn}$ (II) from aquatic environments: an adsorption isotherm study," Environmental Technology, vol. 31, no. 11, pp. 1221-1228, 2010.

[57] J. Anwar, U. Shafique, Waheed-uz-Zaman, M. Salman, A. Dar, and S. Anwar, "Removal of $\mathrm{Pb}(\mathrm{II})$ and $\mathrm{Cd}(\mathrm{II})$ from water by adsorption on peels of banana," Bioresource Technology, vol. 101, no. 6, pp. 1752-1755, 2010.

[58] M. Ghaedi, G. R. Ghezelbash, F. Marahel, S. Ehsanipour, A. Najibi, and M. Soylak, "Equilibrium, thermodynamic, and kinetic studies on lead (II) biosorption from aqueous solution by Saccharomyces cerevisiae biomass," CLEAN-Soil, Air, Water, vol. 38, no. 9, pp. 877-885, 2010. 

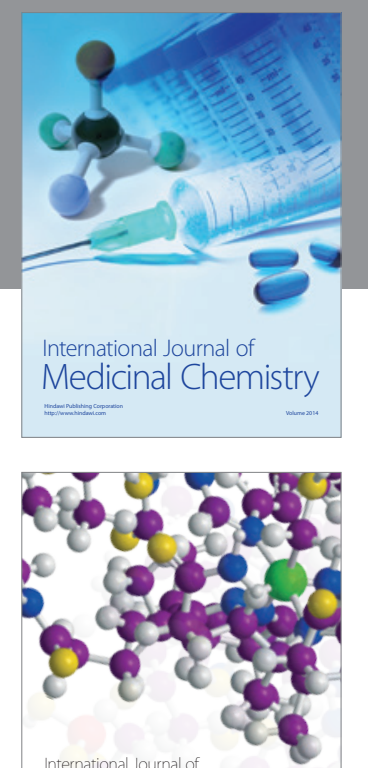

\section{Carbohydrate} Chemistry

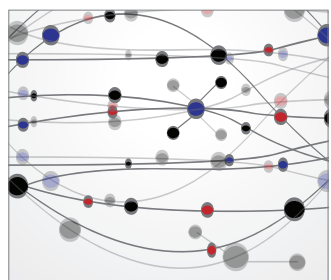

The Scientific World Journal
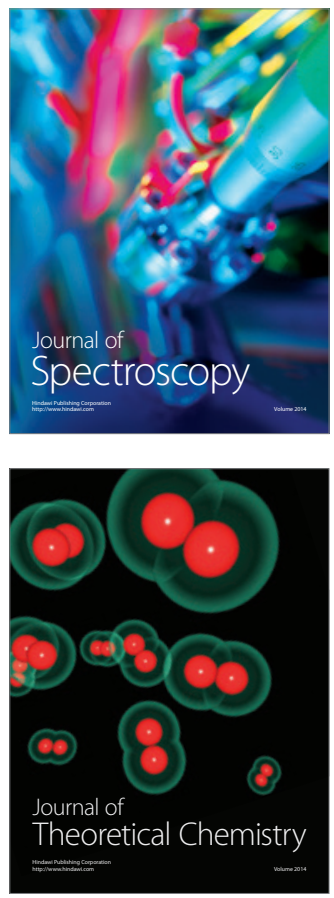
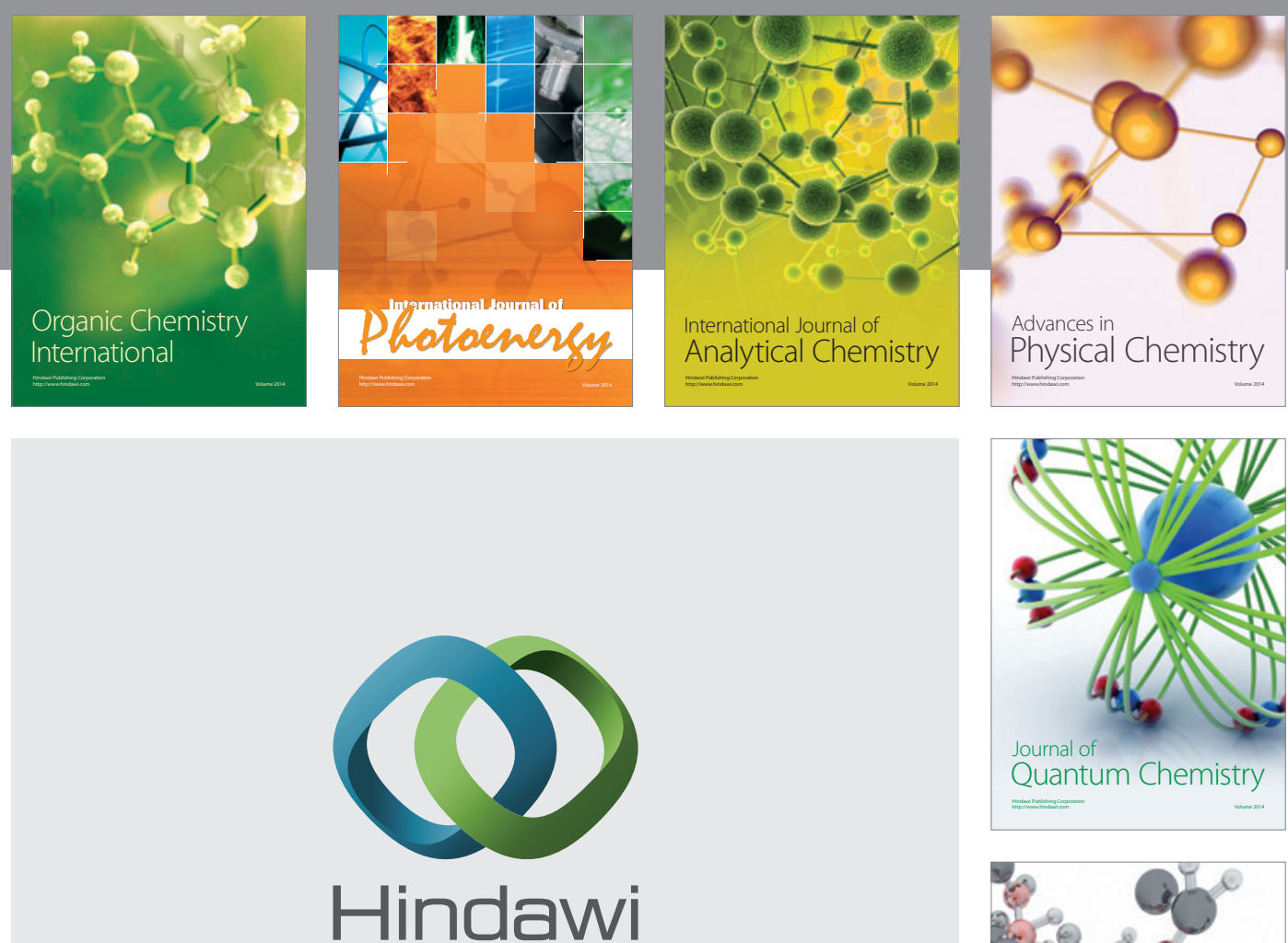

Submit your manuscripts at

http://www.hindawi.com

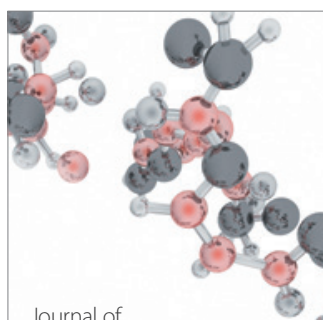

Analytical Methods

in Chemistry

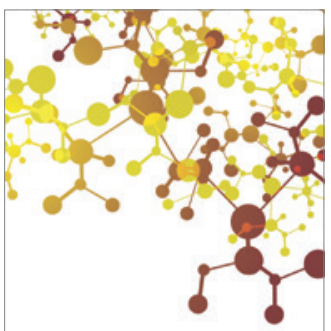

Journal of

Applied Chemistry

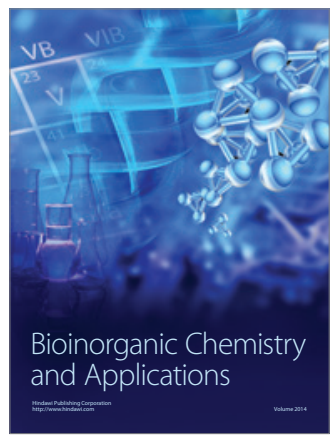

Inorganic Chemistry
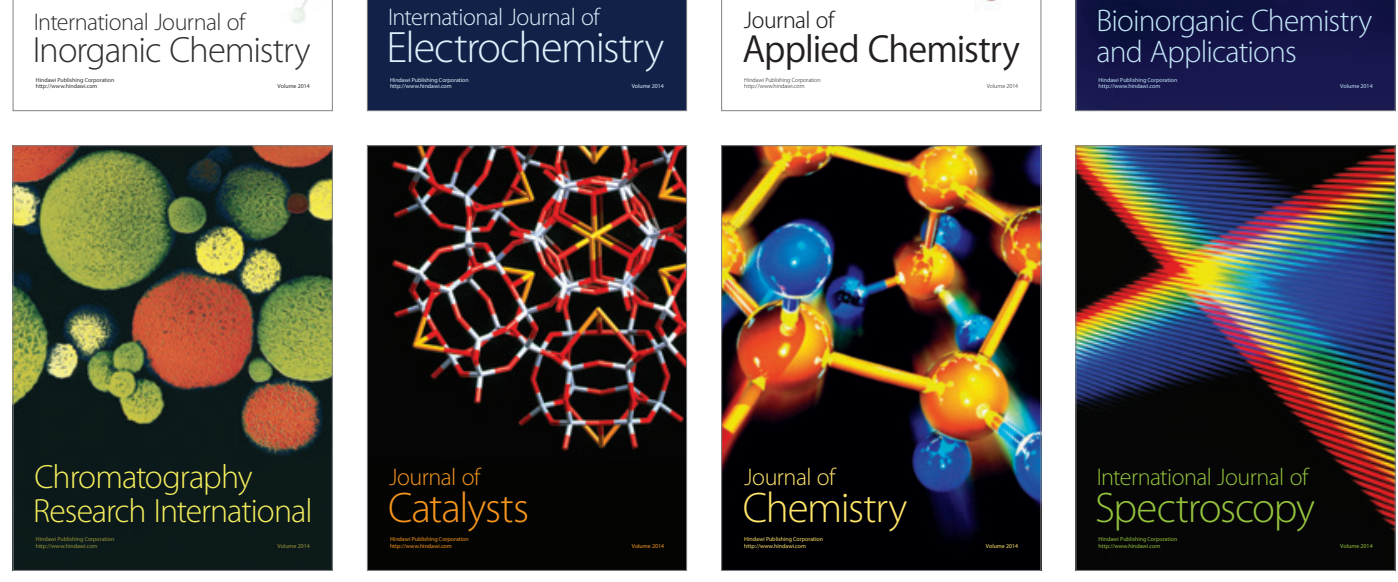